\title{
Genetic analysis of varicella-zoster virus in the aqueous humor in uveitis with severe hyphema
}

\author{
Mayumi Hosogai ${ }^{1,2^{*}}$, Yoko Nakatani ${ }^{2}$, Kensuke Mimura$^{1}$, Shoji Kishi ${ }^{1}$ and Hideo Akiyama ${ }^{1}$
}

\begin{abstract}
Background: Genetic variations have been identified in the genome of varicella-zoster virus (VZV) strains using vesicle fluid, varicella scabs and throat swab samples. We report a rare case of VZV-associated uveitis with severe hyphema, which was immediately diagnosed by polymerase chain reaction (PCR) using the aqueous humor, in which we were able to analyze the VZV genotype for the first time.
\end{abstract}

Case presentation: A 16-year-old Japanese boy was referred to our hospital with a 20-day history of unilateral anterior uveitis and 11-day history of hyphema. At presentation, details of the iris, the iridocorneal angle, and the fundus were not visible due to the severe hyphema. Serum anti-VZV IgG and anti-VZV IgM were elevated, and 1. $61 \times 10^{9}$ copies $/ \mathrm{mL}$ of VZV-DNA were detected by real-time PCR using the aqueous humor. As there were no eruptions on his face or body, we diagnosed zoster sine herpete and started intravenous administration of prednisolone and acyclovir. The hyphema completely disappeared 2 weeks after presentation, while sectorial iris atrophy and mild periphlebitis of the fundus became gradually apparent. Anterior inflammation and periphlebitis gradually improved and VZV-DNA in the aqueous humor was reduced to $1.02 \times 10^{6}$ copies $/ \mathrm{mL}$ at 4 weeks after presentation. Examination by slit lamp microscope revealed no inflammation after 5 months, and VZV-DNA could no longer be detected in the aqueous humor. Serum anti-VZV IgG and anti-VZV IgM also showed a gradual decrease along with improvement in ocular inflammation. The genetic analysis of multiple open reading frames and the R5 variable repeat region in the VZV genes, using DNA extracted from the aqueous humor at presentation, showed that the isolate was a wild-type clade 2 VZV strain (prevalent in Japan and surrounding countries) with R5A allele and one SNP unique to clade 1 (both are major types in Europe and North America).

Conclusions: VZV-associated uveitis may develop hyphema that obscures ocular inflammation, thus PCR analysis using the aqueous humor is the key investigation necessary for the diagnosis. The measurement of VZV-DNA copies by real-time PCR would be useful for evaluation of therapeutic effects. We could amplify and analyze VZV genotype using the aqueous humor including a very large number of VZV-DNA copies $\left(1.61 \times 10^{9}\right.$ copies $\left./ \mathrm{mL}\right)$.

Keywords: Varicella-zoster virus, Herpes zoster ophthalmicus, Zoster sine herpete, Hyphema, Uveitis, Polymerase chain reaction, Genotype, Single nucleotide polymorphism

\footnotetext{
* Correspondence: mayu64jun@gmail.com

'Department of Ophthalmology, Gunma University Graduate School of

Medicine, 3-39-22 Showa-machi, Maebashi, Gunma 371-8511, Japan

${ }^{2}$ Department of Virology and Preventive Medicine, Gunma University

Graduate School of Medicine, 3-39-22 Showa-machi, Maebashi, Gunma

371-8511, Japan
}

(c) The Author(s). 2017 Open Access This article is distributed under the terms of the Creative Commons Attribution 4.0 International License (http://creativecommons.org/licenses/by/4.0/), which permits unrestricted use, distribution, and reproduction in any medium, provided you give appropriate credit to the original author(s) and the source, provide a link to the Creative Commons license, and indicate if changes were made. The Creative Commons Public Domain Dedication waiver (http://creativecommons.org/publicdomain/zero/1.0/) applies to the data made available in this article, unless otherwise stated. 


\section{Background}

Varicella-zoster virus (VZV) is highly contagious and globally ubiquitous. The primary infection results in varicella (chickenpox), which usually occurs early in life. Subsequently, the virus establishes a lifelong latent infection in the sensory nerve ganglia, which reactivates to cause herpes zoster [1].

The VZV genome consists of about 125,000 bases of linear, double-stranded DNA with $\geqq 70$ open reading frames (ORFs). Since the 1990s, a number of genetic variations have been identified in the genome of VZV strains by the use of molecular techniques such as sequencing, restriction fragment length polymorphism (RFLP) and single nucleotide polymorphism (SNP) [2-9]. In 2010, Breuer et al. summarized the previous nomenclature systems and proposed a novel nomenclature for VZV: clade $1-5$ and two putative clades (VI and VII) [10]. In these previous reports, VZV-DNA was extracted from vesicle fluid, varicella scabs or throat swab samples.

Herpes zoster involvement in the ophthalmic division of the first branch of the trigeminal nerve is called herpes zoster ophthalmicus (HZO). HZO without skin lesions is known as zoster sine herpete ( $\mathrm{ZSH})$. VZVassociated uveitis may develop in both $\mathrm{HZO}$ and $\mathrm{ZSH}$ [11]. VZV anterior uveitis is characterised by mutton-fat keratic precipitates, trabecular meshwork pigmentation, ocular hypertension, iris atrophy and distorted pupil. Uveitis sometimes causes hyphema which hides these typical findings $[12,13]$. Few cases of severe hyphema as a complication following VZV-associated uveitis have been reported [14-16]. These cases were diagnosed by clinical findings (e.g., facial skin eruptions) or serum and aqueous humor levels of anti-VZV IgG; however, a confirmed diagnosis is difficult and time-consuming.

Here, we report a rare case of VZV-associated uveitis with severe hyphema, early diagnosed by multiplex polymerase chain reaction (PCR) using the aqueous humor, in which we were able to amplify and analyze the VZV genotype for the first time.

\section{Case presentation}

A 16-year-old Japanese boy was referred to our hospital from an ophthalmology clinic because of severe hyphema in the left eye and anterior uveitis that had persisted for 11 and 20 days, respectively. He was receiving topical treatment with $0.1 \%$ betamethasone, $1 \%$ atropine, $1.5 \%$ levofloxacin, and $0.5 \%$ timolol maleate in the left eye. There was no ocular history of trauma, inflammation, or medication. His family history and medical history for systemic diseases were unremarkable. At presentation, the best corrected visual acuity was 20/15 in the right eye and $20 / 2000$ in the left eye. Intraocular pressure (IOP) was $12 \mathrm{mmHg}$ in the right eye and $29 \mathrm{mmHg}$ in the left eye.
Slit lamp biomicroscopy of the left eye revealed ciliary injection, corneal edema, and severe hyphema filling the anterior chamber (Fig. 1). Due to the severe hyphema, details of the iris, the iridocorneal angle, and the fundus were not visible. No abnormalities were found in the right eye. B-mode echo examination of the left eye revealed no obvious abnormality. In order to exclude the possibility that the hyphema was caused by ocular ischemia, carotid ultrasound was performed, but no obstruction was observed. There was no difference in blood pressure between the two arms suggestive of ocular ischemia caused by Takayasu disease.

Routine blood tests revealed no abnormalities in blood cell counts, blood glucose level, C-reactive protein, immunoglobulins (IgG, IgA, and IgM), antinuclear antibody, or rheumatoid factor. However, anti-VZV IgG and anti-VZV IgM measured by enzyme-linked immunosorbent assays were elevated to $>2600 \mathrm{mIU} / \mathrm{mL}$ (negative: $<50 \mathrm{mIU} / \mathrm{mL}$ ) and 1 : 672 (negative: < 1: 42), respectively. VZV-DNA was not detected in the plasma.

In addition to the laboratory blood tests, we performed an anterior chamber paracentesis of the left eye and extracted DNA from the aqueous humor sample using QIAamp DNA Mini Kit (Qiagen, Valencia, CA). To detect human herpes viruses 1 through 6, multiplex PCR was also performed. VZV-DNA was then detected by multiplex PCR and quantitative real-time PCR revealed $1.61 \times 10^{9}$ copies/mL of VZV-DNA. He had not been vaccinated for VZV and there was history of chickenpox in early childhood. As there were no skin eruptions on his face or body, we diagnosed ZSH and excluded HZO. A detailed examination of the fundus was impossible because of hyphema, so we initiated intravenous administration of acyclovir (500 mg/day) and dexamethasone (6.6 mg/day) based on the possibility of acute retinal necrosis.

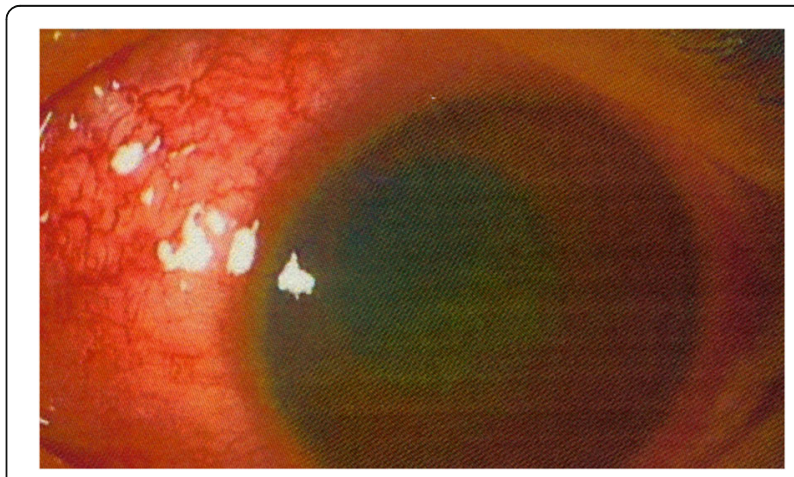

Fig. 1 An anterior photograph of the left eye taken at presentation. Ciliary injection, corneal edema and severe hyphema filling the anterior chamber can be observed. Due to the severe hyphema, details of the iris, the iridocorneal angle and the fundus were not visible 
The hyphema was gradually absorbed and visibility of the anterior chamber improved, revealing inflammation of the anterior chamber and distortion of the pupil (Fig. 2a). A subconjunctival injection of dexamethasone $(1 \mathrm{mg})$ was given in the left eye at 4 days after the initial visit in response to persisting ciliary injection and anterior inflammation. At six days after the initial visit, as the hyphema had diminished, allowing the fundus to be observed, and mild peripheral periphlebitis in the fundus was confirmed.

At two weeks after the initial visit, the hyphema had completely resolved and segmental iris atrophy, which is one of the characteristic ocular manifestations of VZVassociated uveitis, was visible (Fig. 2b). Visual acuity improved to 20/25 and the IOP was $9 \mathrm{mmHg}$ in the left eye. As the periphlebitis also improved, the patient was discharged and the drip was changed to oral famciclovir $(1500 \mathrm{mg} /$ day $)$ and prednisolone $(30 \mathrm{mg} /$ day $)$. As the anterior inflammation and periphlebitis continued to gradually improve thereafter, oral prednisolone was reduced by 5 mg every week.

At 4 weeks after the initial visit, anti-VZV IgG and anti-VZV IgM had decreased to $2500 \mathrm{mIU} / \mathrm{mL}$ and 1 : 168 , respectively. VZV-DNA in the aqueous humor was reduced to $1.02 \times 10^{6}$ copies $/ \mathrm{mL}$. At 2 months after presentation, there was no deterioration in ocular inflammation, so oral famciclovir was reduced to $750 \mathrm{mg} /$ day. At 3 months after presentation, the ciliary injection, anterior inflammation, and periphlebitis had become very mild, and the serum anti-VZV IgG and anti-VZV IgM were further decreased to 1300 $\mathrm{mIU} / \mathrm{mL}$ and 1: 42, respectively. Treatment was continued with oral famciclovir $(750 \mathrm{mg} /$ day $)$ and prednisolone (5 $\mathrm{mg} /$ day).

At 4 months after presentation, as the ciliary injection and inflammation of the anterior chamber had worsened and rubeosis iridis emerged (Fig. 2c, d), a subtenon injection of triamcinolone $(30 \mathrm{mg}$ ) was given to the left eye in addition to the topical and oral medications. After discussing the pros and cons of the therapy and receiving written informed consent, the patient received an intravitreal injection of bevacizumab $(1.25 \mathrm{mg} / 0.05 \mathrm{ml})$.

At 5 months after presentation, visual acuity was $20 / 25$ and the IOP was $10 \mathrm{mmHg}$ in the left eye. The anterior inflammation and periphlebitis had almost completely resolved and the rubeosis iridis had disappeared (Fig. 2e). Slit lamp ophthalmoscopic examination revealed segmental iris atrophy, a distorted pupil, pigmented keratic precipitates, and posterior synechiae. As the retinal periphlebitis had also improved and VZV-DNA in the aqueous humor was not detected by PCR, the oral famciclovir was stopped. However, $5 \mathrm{mg}$ of prednisone every other day and topical medication with $0.1 \%$ betamethasone were continued until 12 months after presentation.

14 months after the initial visit, visual acuity was 20/40 and the IOP was $12 \mathrm{mmHg}$ in the left eye. There was no recurrence of severe inflammation, but a cataract had gradually developed. Anterior segment optical coherence tomography (OCT) images obtained from the CASIA (Tomey, Nagoya, Japan) revealed thinning of the iris in the left eye (Fig. 3). Serum anti-VZV IgG and anti-VZV IgM showed a gradual decrease to $670 \mathrm{mIU} / \mathrm{mL}$ and $<1$ : 42 , respectively.

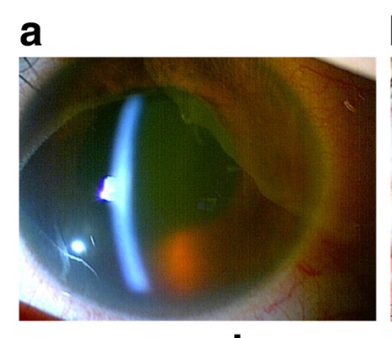

d

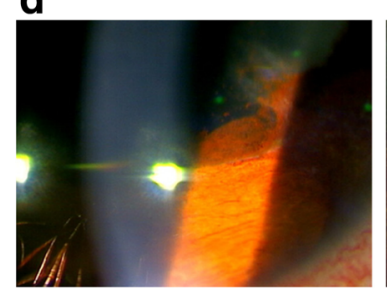

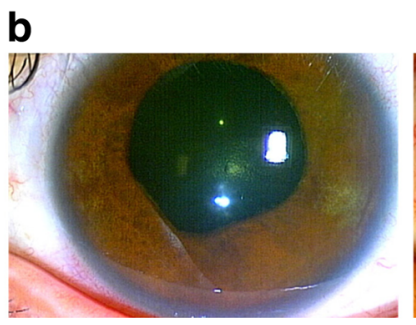

e

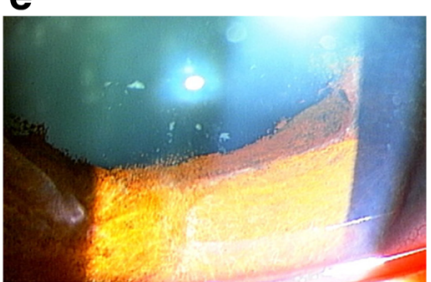

Fig. 2 Anterior photographs of the left eye. a At 2 days after presentation, the hyphema had been partially absorbed and visibility of anterior chamber had improved. b At 2 weeks after presentation, the hyphema had completely disappeared and segmental iris atrophy was revealed. c At 4 months after presentation, segmental iris atrophy, distorted pupil, and posterior synechiae were observed. $\mathbf{d}$ At 4 months after presentation, rubeosis iridis emerged. e At 5 months after presentation, the rubeosis iridis had disappeared and iris atrophy was clearly observable 

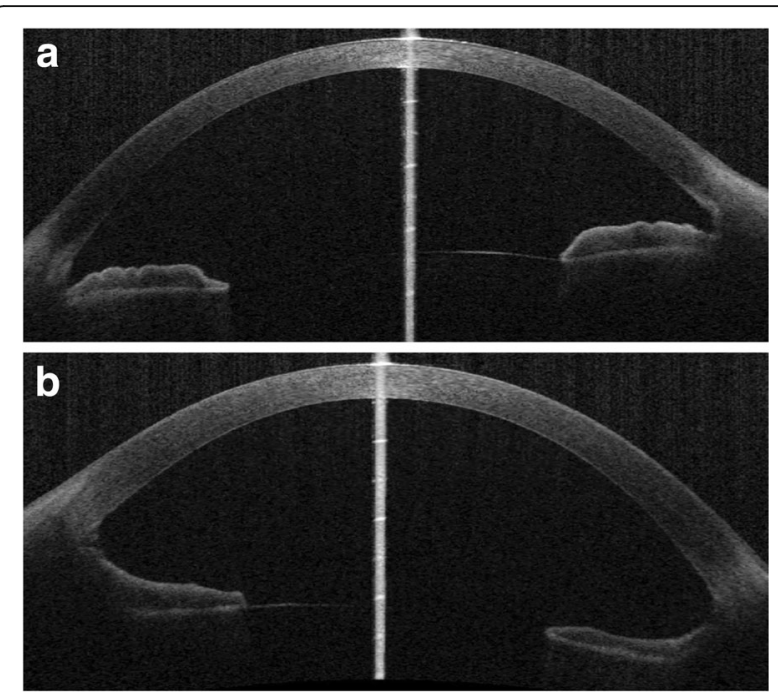

Fig. 3 Anterior segment OCT images obtained from the CASIA OCT at the horizontal meridian. Thinning of the iris is observable in the left eye (b) compared with the right eye (a) at 14 months after presentation

\section{Genetic analysis of VZV}

In order to compare the genotype of the VZV isolate from the aqueous humor of this patient to the previously reported genotypes of the isolates from vesicle fluid, varicella scabs or throat swab samples, we pursued additional genotypic characterization of the VZV strain using DNA extracted from the aqueous humor at the initial visit $\left(1.61 \times 10^{9}\right.$ copies $/ \mathrm{mL}$ of $\mathrm{VZV}$ DNA). Attempts to sequence for VZV genotyping using DNA obtained at 4 weeks after presentation $\left(1.02 \times 10^{6}\right.$ copies $\left./ \mathrm{mL}\right)$ were unsuccessful due to the low viral load. First, we analyzed the RFLPs of ORF38 (PstI), ORF54 (BglI), and ORF62 (SmaI) as previously described [6, 8, 9]. The strain Ellen [17, 18] and the strain Kawaguchi [19] were used to represent the American laboratory VZV and the Japanese wild-type VZV, respectively, as controls. Most VZV isolates in Europe and America, including strain Dumas [20], strain MLS [21], and strain Ellen, contain a PstI restriction enzyme site in ORF38 (positive for the Pst I site: Pst $\mathrm{I}^{+}$). In this case, the PCR products of ORF38 (647 bp) lacked this restriction site (negative for the Pst I site: Pst $\mathrm{I}^{-}$) (Fig. 4a). The PCR products of ORF54 (497 bp) contained the $B g l$ I restriction enzyme site $\left(B g l \mathrm{I}^{+}\right)$and yielded 2 fragments of 256 and $241 \mathrm{bp}$ (Fig. 4b). The PCR products of the Oka vaccine (vOka) strain have three SmaI restriction enzyme sites in ORF62 and yield a set of 112, 79, 41, and 36 bp fragments (positive for the SmaI site: $S m a I^{+}$) [8]. In this patient, the PCR products of ORF62 (268 bp) contained two restriction enzyme sites and were cleaved into a set of 153, 79, and $36 \mathrm{bp}$ fragments (negative for the $S m a \mathrm{I}$ site: $S m a \mathrm{I}^{-}$) like most wild-type VZV strains (Fig. 4c). In summary, RFLPs analysis showed that the isolates from the aqueous humor of this patient were negative for the Pst I site (Pst $\mathrm{I}$ $\left.{ }^{-}\right)$, positive for the $B g l \mathrm{I}$ site $\left(B g l \mathrm{I}^{+}\right)$, and negative for the SmaI site $\left(\mathrm{SmaI}^{-}\right)$, which are typical of Japanese wild-type strains such as the parental Oka (p-Oka) strain and strain Kawaguchi (Table 1).

The R5 variable region between ORF60 and ORF61 has also been shown to vary among different VZV strains. The R5 variable region was amplified by PCR and analyzed by electrophoresis as previously described [6]. This region contains a repeating unit composed of one 88-bp element and one 24-bp element, the copy number of which varied from one to three depending on the VZV strain [22]. The size of the PCR products can be calculated using the following formula, where $n$ represents the number of repeating units:
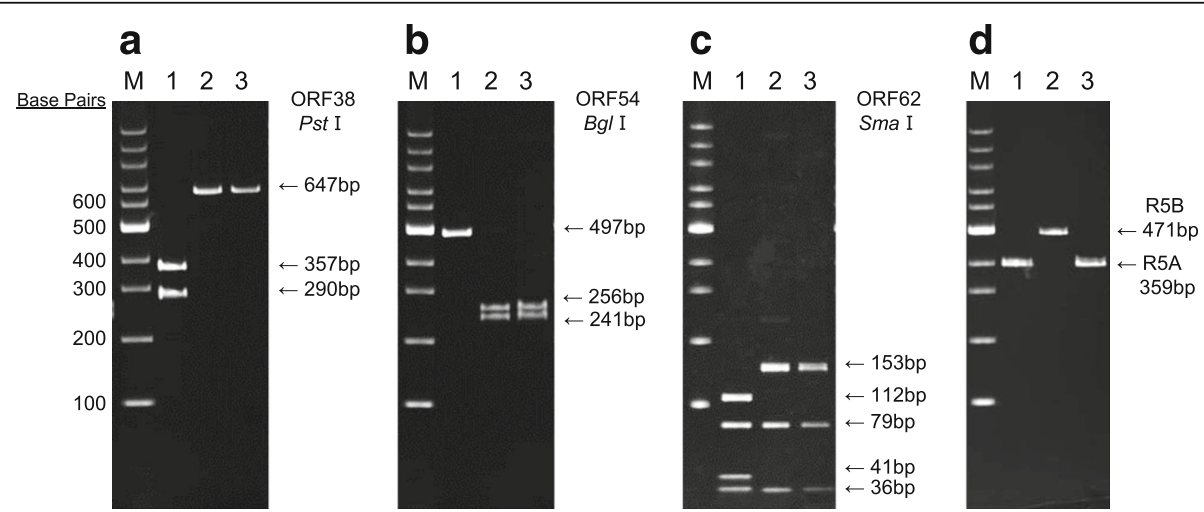

Fig. 4 Genetic analysis of VZV-DNA detected in the aqueous humor. Polyacrylamide gel electrophoresis of the restriction digestion products showing: a Pstl digestion of ORF 38 amplified products, b Bgll digestion of ORF 54 amplified products, and c Smal digestion of ORF 62 amplified products. $\mathbf{d}$ DNA fragments after amplification of the R5 variable region by PCR. Lane M: 100-bp molecular weight ladder. The strain Ellen (Lane 1) and the strain Kawaguchi (Lane 2) were used to represent the American laboratory VZV and the Japanese wild-type VZV, respectively, as controls. Lane 3: DNA fragment from the aqueous humor of this patient at presentation 
Table 1 Genotyping of VZV in the aqueous humor of this patient in reference to the published strain

\begin{tabular}{|c|c|c|c|c|c|c|c|}
\hline VZV strain [Reference] & Origin country & Strain origin & ORF38 (Pstl) & ORF54 (Bgll) & ORF62 (Smal) & R5 type & clade $[10$ \\
\hline Dumas [20] & Netherlands & Varicella & + & - & - & R5A & 1 \\
\hline v-Oka [19] & Japan & Vaccine & - & + & + & R5B & 2 \\
\hline p-Oka [19] & Japan & Varicella & - & + & - & R5B & 2 \\
\hline MLS [21] & USA & Not available & + & + & - & R5A & 5 \\
\hline Ellen $[17,18]$ & USA & Varicella & + & - & + & R5A & 3 \\
\hline Kawaguchi [19] & Japan & Varicella & - & + & - & R5B & 2 \\
\hline this case & Japan & Aqueous humor & - & + & - & R5A & 2 \\
\hline
\end{tabular}

Size of the PCR products (bp)

$$
=24 n+88(n+1)+159
$$

The PCR products of the R5A type are $359 \mathrm{bp}(n=1)$, those of the R5B type are $471 \mathrm{bp}(n=2)$, and those of the $\mathrm{R} 5 \mathrm{C}$ type are $583 \mathrm{bp}(n=3)$. In this patient, R5A (mainly found in Europe and North America) was observed unlike Japanese strains (v-Oka, p-Oka, and Kawaguchi) (Fig. 4d and Table 1).

Additionally, the amplicons of ORFs 1, 6, 12, 16, 17, $21,22,35,37,50,54,55,56,60,62$, and 66 were sequenced as previously described [21, 23]. The 27 SNPs of these ORFs were previously proposed for the classification of VZV strains [10]. The informative polymorphic markers on the regions are shown in Fig. 5. Based on the nomenclature scheme proposed by Breuer et al. [10], the VZV isolate from the aqueous humor of this patient was grouped among the clade 2 strains, a genotype predominantly present in Japan and surrounding countries $[4,9]$. In addition, we found three SNPs that differed from those of clade 2, in which one SNP ( $\mathrm{C}$ at position 87841 ) was unique to clade 1 , the dominant clade in Europe and North America.

\section{Discussion}

We experienced a rare case of VZV-associated uveitis with severe hyphema in an immunocompetent boy without eruptions or vaccination history. The clinical findings, such as unilateral uveitis with elevated IOP, segmental iris atrophy, and distorted pupil, were compatible with the characteristics of VZV-associated uveitis [24]. A definitive diagnosis of ZSH can be made by detecting VZV-DNA in the aqueous humor [25]. In this case, because VZV-DNA was detected in the aqueous humor by multiplex PCR at presentation, we could make a definitive diagnosis and start treatment at an early stage. Quantitative real-time PCR revealed that a large number of VZV-DNA copies were present in the aqueous humor, which decreased and disappeared as ocular inflammation improved with acyclovir/famciclovir treatment.
Antibody examination is also useful in the diagnosis of $\mathrm{ZSH}$ [26]. In the present case, a gradual decrease was observed in serum anti-VZV IgG and serum anti-VZV IgM along with improvement in ocular inflammation, and these findings were also useful in the evaluation of therapeutic effects.

In most cases of uveitis with hyphema, the cause of bleeding is supposed to be rubeosis iridis [12]. In VZVassociated uveitis, iris fluorescein angiography suggests occlusive vasculitis to be the main cause of the iris lesion responsible for the bleeding [14, 27]. At the initial visit, the rubeosis iridis could not be observed due to severe hyphema and iris fluorescein angiography was not performed. Taking into account the fact that rubeosis iridis developed at 4 months after the initial visit, the hyphema may have been due to rubeosis iridis. Moreover, the marked iris atrophy observed after the resolution of inflammation suggests the presence of severe inflammation that may have caused obstruction of the iris vessels.

Genetic variations have been identified in the genome of VZV strains from vesicle fluid, varicella scabs or throat swab samples by molecular techniques [2-9]. However, there have been no reports on the genotyping of VZV using DNA extracted from the aqueous humor. It is generally considered that genetic analysis using the aqueous humor is difficult as we can only collect a small amount of aqueous humor and it contains only little or incomplete VZV genomes. Kido et al. reported that quantitative real-time PCR detected significant viral loads of VZV-DNA (ranging from $3.86 \times 10^{2}$ to $1.26 \times 10^{7}$ copies $/ \mathrm{mL}$ ) in the aqueous humor of eight patients with VZV-associated uveitis [25]. In this case, quantitative real-time PCR revealed that a very large number of VZV-DNA copies were present $\left(1.61 \times 10^{9}\right.$ copies $/ \mathrm{mL}$ ) in the aqueous humor at presentation, which subsequently fell to $1.02 \times 10^{6}$ copies $/ \mathrm{mL}$ at 4 weeks after presentation. We could analyze the VZV genotype using DNA obtained at presentation, but not with DNA obtained at 4 weeks after presentation. This is a valuable report in terms of our ability to obtain a very large number of VZV-DNA copies and analyze VZV genotype 


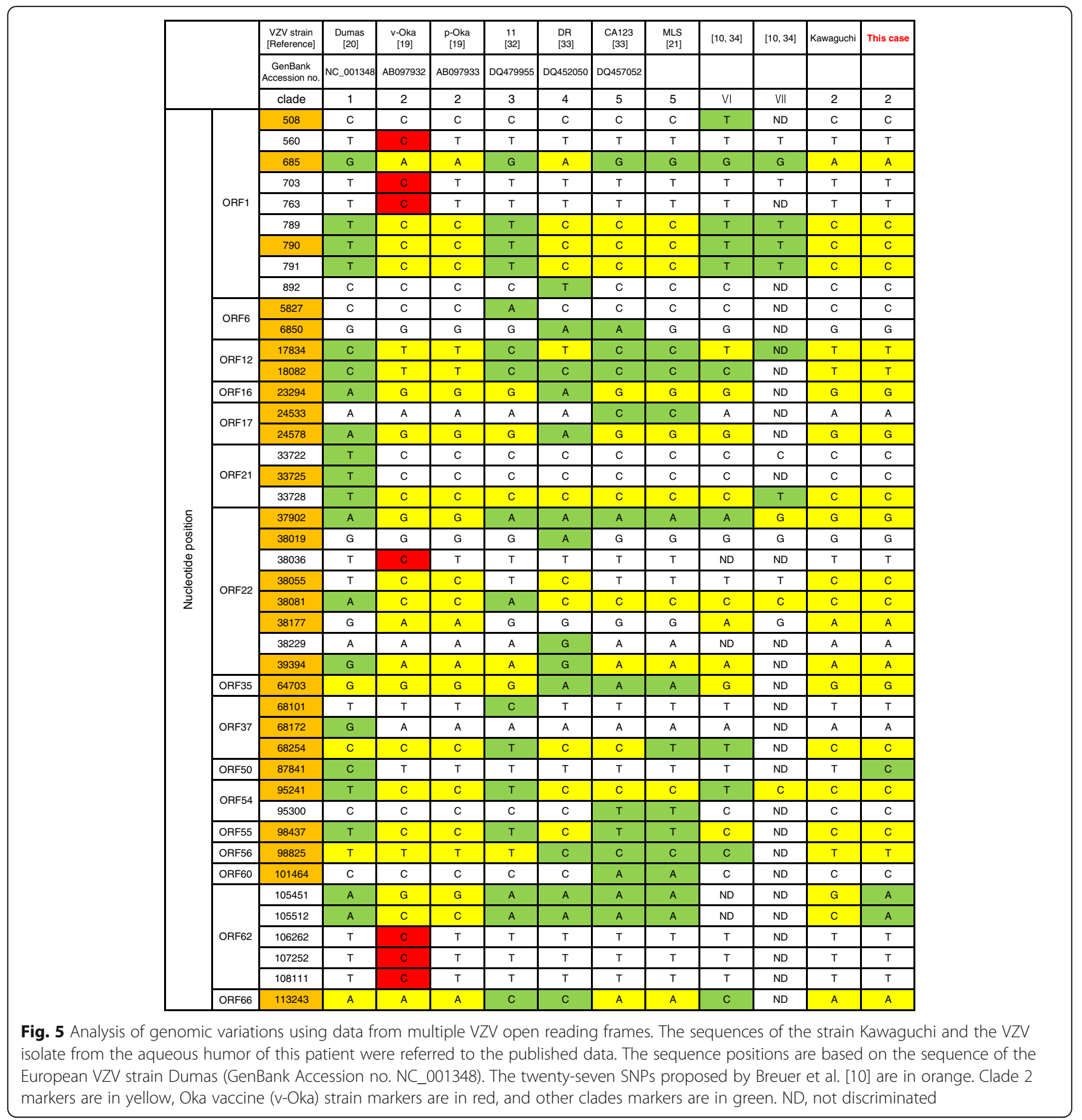

using the aqueous humor. To the best of our knowledge, this is the first investigation of VZV genotype to use aqueous humor.

RFLPs analysis of VZV strains have identified a relationship between VZV genotype and climate. ORF38 (PstI), ORF54 (BglI) and ORF62 (SmaI) in the VZV genes are molecular genetic markers for the genotyping of VZV strains $[9,28,29]$. Previous studies have shown that the absence of a Pst $\mathrm{I}$ restriction site $\left(P s t \mathrm{I}^{-}\right)$in $\mathrm{ORF}$ 38 and the presence of a $B g l \mathrm{I}$ restriction site $\left(B g l \mathrm{I}^{+}\right)$in
ORF 54 differentiate v-Oka from wild-type American strains [28, 29], such as strain MLS, and European strains $[6,30]$, such as strain Dumas. The differences reflect geographical variations between the Japanese v-Oka and non-Japanese strains, but these markers do not distinguish v-Oka from its parent wild-type virus (p-Oka) or from other wild-type Japanese strains such as strain Kawaguchi [31]. By analyzing the SmaI restriction enzyme cleavage sites in ORF 62, which only v-Oka creates, v-Oka can be differentiated from p-Oka and 
other wild-type Japanese strains [8]. In the present study, the VZV isolates in the aqueous humor of this patient were $P_{s t \mathrm{I}^{-}}$in ORF38, $B g l \mathrm{I}^{+}$in ORF54, and $\mathrm{SmaI}^{-}$in ORF 62 (Fig. 4 and Table 1). These results are consistent with the findings for wild-type Japanese VZV strains.

The R5 variable region in the VZV genes has also been shown to have geographic variations $[6,21,30]$. The R5A (359 bp) type is mainly found in Europe and North America, including strain Dumas, strain MLS, and strain Ellen. The R5B (471 bp) type is a major type in Japan, including strain v-Oka, p-Oka, and Kawaguchi. Unlike these Japanese strains, R5A was observed in the current patient (Fig.4d and Table 1).

With the development of whole-genome sequencing, a meeting, held in 2008, was organized to create a common system for VZV classification and nomenclature. Based on the phylogeny of VZVs, five major clades (1-5) and two provisional clades (VI and VII) were proposed [10]. Multiple ORFs required for this classification in VZV genes have been sequenced and analyzed in various areas of the world [2, 9, 21, 23]. By referring to the SNPs, the VZV strain from the aqueous humor of this patient could be grouped among clade 2 strains, a genotype commonly found in Japan and surrounding countries $[4,9,10]$. Additionally, we found three SNPs that differed from those of clade 2, in which one SNP ( $\mathrm{C}$ at position 87841) was unique to clade 1 (Fig. 5). It is likely that this strain may represent a new subclade of clade 2 .

As there have been no reports on the genotyping of VZV in uveitis using aqueous humor, it is unknown whether this genotype is specific to uveitis or whether it differs from varicella or herpes zoster. Despite the thorough investigation of genetic variability among the circulating strains of VZV in recent decades, it is not yet known whether VZV genotype is linked to differences in the pathogenesis and virulence of VZV strains. One of the important limitations to this report is that we were not able to analyze any other VZV-DNA sequences from this patient to which the aqueous humor genomes could be compared as VZVDNA was not detected in the plasma and no other specimens, such as throat swabs, could be collected at presentation. Therefore, future studies are warranted to analyze VZV genotypes using the aqueous humor, as performed in this study, as well as other specimens where possible in a large number of uveitis cases.

\section{Conclusions}

In conclusion, we report a rare case of $\mathrm{ZSH}$ with severe hyphema, which was diagnosed by multiplex PCR using the aqueous humor at an early stage. The measurement of VZV-DNA copy numbers by quantitative real-time PCR, as well as serum anti-VZV IgG and serum anti-
VZV IgM was useful for the evaluation of improvement in ocular inflammation and therapeutic effects. As far as we know, this is the first report that we could amplify and analyze VZV genotype using the aqueous humor including a very large number of VZV-DNA copies $\left(1.61 \times 10^{9}\right.$ copies $\left./ \mathrm{mL}\right)$. Genetic analysis showed that the isolate from the aqueous humor of this patient was a wild-type clade 2 VZV strain (prevalent in Japan and surrounding countries) with R5A allele and one SNP unique to clade 1 (both are mainly found in Europe and North America).

\section{Abbreviations \\ HZO: Herpes zoster ophthalmicus; IOP: Intraocular pressure; OCT: Optical coherence tomography; ORF: Open reading frame; PCR: Polymerase chain reaction; p-Oka: Parental Oka; RFLP: Restriction fragment length polymorphism; SNP: Single nucleotide polymorphism; v-Oka: Oka vaccine; VZV: Varicella-zoster virus; ZSH: Zoster sine herpete.}

\section{Acknowledgements}

We thank Dr. Kimiyasu Shiraki (Department of Virology, University of Toyama) for providing the American laboratory VZV strain (strain Ellen). We would also like to thank the patient and his mother for their participation in this study.

\section{Funding}

This work was financially supported by a Grant-in-Aid for Young Scientists for the genetic analysis of VZV (16 K20304 to MH). The funder had no role in the design of the study, the collection, analysis, and interpretation of data or in writing the manuscript.

\section{Availability of data and materials \\ The datasets supporting the conclusions of this article are included within the article.}

\section{Authors' contributions}

$\mathrm{MH}, \mathrm{KM}, \mathrm{SK}$, and HA carried out the clinical follow up. MH and $\mathrm{YN}$ performed laboratory analysis. MH wrote the first manuscript draft. MH, SK, and HA contributed to the interpretation of the data and critically revised the manuscript. All authors read and approved the final manuscript.

\section{Competing interests}

The authors declare that they have no competing interests.

\section{Consent for publication}

Written informed consent for publication of this case report and accompanying images was obtained from the patient's mother. A copy of the written consent is available for the journal.

\section{Ethics approval and consent to participate}

Not applicable.

Received: 2 February 2017 Accepted: 1 June 2017

Published online: 15 June 2017

\section{References}

1. Becerra JC, Sieber R, Martinetti G, Costa ST, Meylan P, Bernasconi E. Infection of the central nervous system caused by varicella zoster virus reactivation: a retrospective case series study. Int J Infect Dis. 2013;17(7):e529-34.

2. Barrett-Muir W, Scott FT, Aaby P, John J, Matondo P, Chaudhry QL, et al. Genetic variation of varicella-zoster virus: evidence for geographical separation of strains. J Med Virol. 2003;70(Suppl 1):S42-7.

3. Carr MJ, McCormack GP, Crowley B. Genetic variation in clinical varicella-zoster virus isolates collected in Ireland between 2002 and 2003. J Med Virol. 2004;73(1):131-6.

4. Muir WB, Nichols R, Breuer J. Phylogenetic analysis of varicella-zoster virus: evidence of intercontinental spread of genotypes and recombination. J Virol. 2002;76(4):1971-9. 
5. Faga B, Maury W, Bruckner DA, Grose C. Identification and mapping of single nucleotide polymorphisms in the varicella-zoster virus genome. Virology. 2001;280(1):1-6.

6. Hawrami K, Breuer J. Analysis of United Kingdom wild-type strains of varicella-zoster virus: differentiation from the Oka vaccine strain. J Med Virol. 1997:53(1):60-2.

7. Hawrami K, Harper D, Breuer J. Typing of varicella zoster virus by amplification of DNA polymorphisms. J Virol Methods. 1996:57(2):169-74.

8. Loparev VN, Argaw T, Krause PR, Takayama M, Schmid DS. Improved identification and differentiation of varicella-zoster virus (VZV) wild-type strains and an attenuated varicella vaccine strain using a VZV open reading frame 62-based PCR. J Clin Microbiol. 2000;38(9):3156-60.

9. Loparev VN, Gonzalez A, Deleon-Carnes M, Tipples G, Fickenscher H, Torfason EG, et al. Global identification of three major genotypes of varicella-zoster virus: longitudinal clustering and strategies for genotyping. J Virol. 2004;78(15):8349-58.

10. Breuer J, Grose C, Norberg P, Tipples G, Schmid DS. A proposal for a common nomenclature for viral clades that form the species varicella-zoster virus: summary of VZV nomenclature meeting 2008, Barts and the London School of Medicine and dentistry, 24-25 July 2008. J Gen Virol. 2010;91(Pt 4):821-8.

11. Liesegang TJ. Herpes zoster virus infection. Curr Opin Ophthalmol. 2004; 15(6):531-6.

12. Fong DS, Raizman MB. Spontaneous hyphema associated with anterior uveitis. Br J Ophthalmol. 1993;77(10):635-8.

13. Liesegang TJ. Clinical features and prognosis in Fuchs' uveitis syndrome. Arch Ophthalmol. 1982;100(10):1622-6.

14. Akpek EK, Gottsch JD. Herpes zoster sine herpete presenting with hyphema Ocul Immunol Inflamm. 2000;8(2):115-8.

15. Hayasaka S, Watanabe M, Yamamoto Y, Noda S, Sekimoto M, Setogawa T. Herpes zoster ophthalmicus complicated by hyphema and hemorrhagic glaucoma. Ophthalmologica. 1988;196(4):185-7.

16. Okunuki Y, Sakai J, Kezuka T, Goto H. A case of herpes zoster uveitis with severe hyphema. BMC Ophthalmol. 2014;14:74

17. Brunell PA, Casey HL. Crude tissue culture antigen for determination of varicella-zoster complement fixing antibody. Public Health Rep. 1964;79:839-42.

18. Peters GA, Tyler SD, Carpenter JE, Jackson W, Mori Y, Arvin AM, et al. The attenuated genotype of varicella-zoster virus includes an ORF0 transitional stop codon mutation. J Virol. 2012;86(19):10695-703.

19. Gomi Y, Sunamachi H, Mori Y, Nagaike K, Takahashi M, Yamanishi K. Comparison of the complete DNA sequences of the Oka varicella vaccine and its parental virus. J Virol. 2002;76(22):11447-59.

20. Davison AJ, Scott JE. The complete DNA sequence of varicella-zoster virus. J Gen Virol. 1986;67(Pt 9):1759-816.

21. Liu J, Wang M, Gan L, Yang S, Chen J. Genotyping of clinical varicella-zoster virus isolates collected in China. J Clin Microbiol. 2009;47(5):1418-23.

22. Hondo R, Yogo Y. Strain variation of R5 direct repeats in the right-hand portion of the long unique segment of varicella-zoster virus DNA. J Virol. 1988:62(8):2916-21.

23. Loparev VN, Rubtcova EN, Bostik V, Tzaneva V, Sauerbrei A, Robo A, et al. Distribution of varicella-zoster virus (VZV) wild-type genotypes in northern and southern Europe: evidence for high conservation of circulating genotypes. Virology. 2009;383(2):216-25.

24. Takase H, Kubono R, Terada Y, Imai A, Fukuda S, Tomita M, et al. Comparison of the ocular characteristics of anterior uveitis caused by herpes simplex virus, varicella-zoster virus, and cytomegalovirus. Jpn $J$ Ophthalmol. 2014;58(6):473-82.

25. Kido S, Sugita S, Horie S, Miyanaga M, Miyata K, Shimizu N, et al. Association of varicella zoster virus load in the aqueous humor with clinical manifestations of anterior uveitis in herpes zoster ophthalmicus and zoster sine herpete. Br J Ophthalmol. 2008;92(4):505-8.

26. Witmer R. Clinical implications of aqueous humor studies in uveitis. Am J Ophthalmol. 1978;86(1):39-44.

27. Marsh RJ, Easty DL, Jones BR. Iritis and iris atrophy in herpes zoster ophthalmicus. Am J Ophthalmol. 1974;78(2):255-61.

28. LaRussa P, Lungu O, Hardy I, Gershon A, Steinberg SP, Silverstein S. Restriction fragment length polymorphism of polymerase chain reaction products from vaccine and wild-type varicella-zoster virus isolates. J Virol. 1992;66(2):1016-20.

29. LaRussa P, Steinberg S, Arvin A, Dwyer D, Burgess M, Menegus M, et al. Polymerase chain reaction and restriction fragment length polymorphism analysis of varicella-zoster virus isolates from the United States and other parts of the world. J Infect Dis. 1998:178(Suppl 1):S64-6.

30. Sauerbrei A, Eichhorn U, Gawellek S, Egerer R, Schacke M, Wutzler P. Molecular characterisation of varicella-zoster virus strains in Germany and differentiation from the Oka vaccine strain. J Med Virol. 2003;71(2):313-9.

31. Takada M, Suzutani T, Yoshida I, Matoba M, Azuma M. Identification of varicella-zoster virus strains by PCR analysis of three repeat elements and Pstl-site-less region. J Clin Microbiol. 1995;33(3):658-60.

32. Peters GA, Tyler SD, Grose C, Severini A, Gray MJ, Upton C, et al. A full-genome phylogenetic analysis of varicella-zoster virus reveals a novel origin of replication-based genotyping scheme and evidence of recombination between major circulating clades. J Virol. 2006;80(19):9850-60.

33. Norberg P, Liljegvist JA, Bergstrom T, Sammons S, Schmid DS, Loparev VN Complete-genome phylogenetic approach to varicella-zoster virus evolution: genetic divergence and evidence for recombination. J Virol. 2006;80(19):9569-76

34. Loparev VN, Rubtcova EN, Bostik V, Govil D, Birch CJ, Druce JD, et al. Identification of five major and two minor genotypes of varicella-zoster virus strains: a practical two-amplicon approach used to genotype clinical isolates in Australia and New Zealand. J Virol. 2007:81(23):12758-65.

\section{Submit your next manuscript to BioMed Central and we will help you at every step:}

- We accept pre-submission inquiries

- Our selector tool helps you to find the most relevant journal

- We provide round the clock customer support

- Convenient online submission

- Thorough peer review

- Inclusion in PubMed and all major indexing services

- Maximum visibility for your research

Submit your manuscript at www.biomedcentral.com/submit
) Biomed Central 